\title{
The role of Human papillomavirus in surface epithelial ovarian carcinoma with its effect on P53 and Retinoblastoma tumor suppressor genes
}

\author{
Sana'a M. H. Alizi ${ }^{1}$, Faiza A. Mukhlis ${ }^{2}$, Ban A. Abdul-Majeed ${ }^{3}$ \\ - Virologist /Ph.D. Degree/ Director of HPV Program / Department of Molecular biology / Central public health \\ lab/ Baghdad/Iraq ${ }^{(1)}$ \\ - Professor / Ph.D. degree/Consultant of Virology/Department of Microbiology/College of medicine / Baghdad \\ University $^{(2)}$ \\ - Professor / Ph.D. degree/ Consultant of Molecular Pathology and genetics/Department of pathology/ College of \\ medicine / Alnahrain University ${ }^{(3)}$
}

\begin{abstract}
Background: Human papillomaviruses (HPV) has a particular tropism for the epithelium inducing its proliferation. It has been shown that E6 and E7 protein is capable of binding and inactivating the P53 and Retinoblastoma $(R b)$ tumor suppressor genes. These interactions are responsible for the transforming activity of $H P V$.

Objectives of the study: Estimation of any possible association of HPV low and high risk types with P53 and Rb tumor suppressor genes in surface epithelial ovarian carcinoma compared to benign and control groups.

Materials And Methods: This study involved 76 ovarian tissue blocks which prepared for detecting and localization the DNA of high risk HPV (16\&18) and low risk HPV (6\&11) types in comparison with the presence of wild type P53 and Rb mRNA signals by using in situ hybridization (ISH) technique. Immunohistochemistry (IHC) technique was used to demonstrate the over-expression state of p53 tumor suppressor protein.

Results: onlyHPV6 appeared significant association with P53 mRNA ISH signal in benign group and only HPVI8 showed significant association with Rb-ISH mRNA in benign group.On the other hand significant association was found between P53 IHC signal and HPVII ISH signal also in benign group.

Conclusions: Furthermore, a positive correlation between HPV and p53 expressions in ovarian cancer tissue samples was detected. HPV does not seem to be a major component in the development of ovarian carcinoma, nevertheless HPV positivity seems to contribute to the pathogenesis in at least some ovarian carcinoma cases by way of interaction with tumor suppressor $p 53$.
\end{abstract}

Key words: In situ hybridization, HPV, and ovarian carcinoma, P53, and Rb.

\section{Introduction}

Human papillomaviruses (HPVs) are small double-stranded DNA viruses featuring oncogenic properties. They infect mucosal and skin epithelia (Jawetz et al., 2004). Viruses encode proteins which inactivate the $\mathrm{Rb} / \mathrm{p} 53$ check points. For example, viral early proteins E6 -E7 are synthesized in cancer tissue, these are HPV transforming proteins able to complex with p53 (Werness et al., 1990) and Rb (Dyson et al., 1989). The etiology of ovarian cancer is multifactorial but it is still remains unclear (Boyle et al., 2000). The involvement of HPV infection in epithelial ovarian cancer has been an interesting issue.

\section{Subjects, materials and methods}

The study was designed as a retrospective one. It involved 76 selected formalin fixed, paraffin embedded ovarian tissue blocks including 28 blocks of surface epithelial ovarian carcinomas, 28 blocks of benign epithelial ovarian tumors, and 20 blocks of normal ovarian tissues as a control. Specimens were collected during the period from June 2007 to June 2010 from the Medical City Teaching Hospital, Al-Elweiya hospital, and the private laboratories in Baghdad. The diagnosis of these tissue blocks were based on the obtained pathological records of these cases from hospital files as well as histopathological laboratories records. A confirmatory histopathological re-examination of each obtained tissue blocks was done.

In Situ hybridization technique done by using Hybridization/Detection system (Maxim Biotech Inc. USA) to target DNA sequences of HPVand RNA of both p53 and RB in tissue specimens. Proper use of this hybridization/detection system will give an intense blue signal at the specific site of the hybridization probe in positive test tissue. Quantification of different molecular markers in situ hybridization signal was evaluated under light microscopy at X100, X400, and oil immersion (X1000) respectively. The counting of positive cells was performed at X1000. 
Immunohistochemistry kit was used for detection of p53 protein (Dako, Denmark). A biotinylated, crossadsorbed, and affinity purified secondary anti-mouse $\mathrm{IgG}$ was used to detect primary antibody-antigen complexes adhered to a glass microscope slide, following reaction with an enhanced detection reagent, proper and accurate application of kit instructions led to appearance of a brown precipitate in positive cells on tissue sections. Quantification of P53 protein expression was evaluated under light microscopy at X100, X400, and X1000. The counting of positive cells was performed at X1000.

In situ hybridization and immunohistochemistry was given intensity and percentage scores, based on intensity of positive signals and number of signals, respectively. A scale of 0-3 was used for relative intensity with 0 corresponding to no detectable ISH reaction and 1,2, 3 equivalent to low, moderate, and high intensity of reaction respectively. Positive cells were counted in ten different fields of 100 cells for each sample and the average of positive cells of the ten fields was determined assigning cases to one of the three following score categories:Score(1)=1-25\%, Score(2)=26-50\%, Score(3)>50\% (Zlobec et al., 2006).

\section{Results}

\section{ISH P53 mRNA With High And Low Risk Types of HPV DNA}

In malignant group the percentage of positive results for both P53 mRNA and HPV DNA were 6cases (21.4\%) for HPV16 and 3 cases (10.7\%) for HPV18. In benign group the percentage was 3 cases $(10.7 \%)$ for both(Table -1).

Table (2) shows the association between the presence of low risk types of HPV DNA and P53 mRNA. In malignant group the percentage of positive results for both P53 mRNA and HPV DNA was $10.7 \%$ for both HPV6 and HPV 11 while it was $7.1 \%$ for HPV6 and 14.3\% for HPV11 in benign group.

Table (1): Association between wild type of P53 and high risk types of human papillomavirus (HPV 16 and 18)

\begin{tabular}{|c|c|c|c|c|c|c|c|}
\hline \multirow[t]{2}{*}{ Groups } & \multirow{2}{*}{$\begin{array}{l}\text { ISH results of } \\
\text { P53 }\end{array}$} & \multicolumn{3}{|c|}{ HPV 16 results } & \multicolumn{3}{|c|}{ HPV 18 results } \\
\hline & & Negative & Positive & Chi-Square Tests & Negative & Positive & Chi-Square Tests \\
\hline \multirow[t]{3}{*}{ Malignant } & Negative & $11 / 28$ & $5 / 28$ & \multirow{3}{*}{$\begin{array}{c}1 \\
\text { Chi-Square:0.01 } \\
\text { p-value: } 0.99 \\
\text { p value }>0.05 \\
\text { non significant }\end{array}$} & & & \multirow{3}{*}{$\begin{array}{c}2 \\
\text { Chi-Square:1.35 } \\
\text { p-value: } 0.18 \\
\text { p value>0.05 } \\
\text { non significant }\end{array}$} \\
\hline & & $39.5 \%$ & $17.9 \%$ & & $32.14 \%$ & $25 \%$ & \\
\hline & Positive & $\begin{array}{c}6 / 28 \\
21.4 \%\end{array}$ & $\begin{array}{c}6 / 28 \\
21.4 \%\end{array}$ & & $\begin{array}{c}9 / 28 \\
32.14 \%\end{array}$ & $\begin{array}{c}3 / 28 \\
10.72 \%\end{array}$ & \\
\hline \multirow[t]{3}{*}{ Benign } & Negative & $12 / 28$ & $10 / 28$ & \multirow{3}{*}{$\begin{array}{c}3 \\
\text { Chi-Square:1.63 } \\
\text { p-value:0.104 } \\
\text { p value }>0.05 \\
\text { non significant }\end{array}$} & $13 / 28$ & & \multirow{3}{*}{$\begin{array}{c}4 \\
\text { Chi-Square: } 1.63 \\
\text { p-value: } 0.104 \\
\text { p value }>0.05 \\
\text { non significant }\end{array}$} \\
\hline & & $42.85 \%$ & $35.71 \%$ & & $46.5 \%$ & $32.1 \%$ & \\
\hline & Positive & $\begin{array}{c}3 / 28 \\
10.72 \%\end{array}$ & $\begin{array}{c}3 / 28 \\
10.72 \%\end{array}$ & & $\begin{array}{c}3 / 28 \\
10.7 \%\end{array}$ & $\begin{array}{c}3 / 28 \\
10.7 \%\end{array}$ & \\
\hline \multirow[t]{3}{*}{ Control } & Negative & $18 / 20$ & $0 / 20$ & \multirow{3}{*}{$\begin{array}{c}5 \\
\text { Chi-Square:0.73 } \\
\text { p-value: } 0.468 \\
\text { p value }>0.05 \\
\text { non significant }\end{array}$} & & & \multirow{3}{*}{$\begin{array}{c}6 \\
\text { Chi-Square:0.73 } \\
\text { p-value: } 0.468 \\
\text { p value }>0.05 \\
\text { non significant }\end{array}$} \\
\hline & & $90 \%$ & $0 \%$ & & $90 \%$ & $0 \%$ & \\
\hline & Positive & $\begin{array}{l}2 / 20 \\
10 \%\end{array}$ & $\begin{array}{c}0 / 20 \\
0 \%\end{array}$ & & $\begin{array}{l}2 / 20 \\
10 \%\end{array}$ & $\begin{array}{c}0 / 20 \\
0 \%\end{array}$ & \\
\hline \multicolumn{2}{|c|}{$\begin{array}{l}\text { Chi-Square Tests among } \\
\text { study groups }\end{array}$} & \multicolumn{3}{|c|}{$\begin{array}{l}7 \\
\text { chi-square: } 5.18 \\
\text { DF: } 2, p \text {-value: } 0.075108 \\
p>0.05, \text { Non Significant }\end{array}$} & \multicolumn{3}{|c|}{$\begin{array}{l}8 \\
\text { chi-square: } 2.32 \\
\text { DF: } 2, p \text {-value: } 0.312991 \\
p>0.05 \quad, \text { Non Significant }\end{array}$} \\
\hline
\end{tabular}

- $1,2,3,4,5$, and 6 refer to that no significant $(\mathrm{P}>0.05)$ association between of P53 mRNA ISH signal and each of HPV16 and HPV18 ISH signal in each of malignant, benign and control group.

- 7 and 8 refer to that no significant difference $(P>0.05)$ was found among study groups regarding the association between P53 mRNA and each of HPV16 \& HPV18.

Table (2): Association between wild type of P53 and low risk types of human papillomavirus (HPV 6 and 11)

\begin{tabular}{|c|c|c|c|c|c|c|c|}
\hline \multirow[t]{2}{*}{ Groups } & \multirow{2}{*}{$\begin{array}{l}\text { ISH results } \\
\text { of P53 }\end{array}$} & \multicolumn{3}{|c|}{ HPV 6 results } & \multicolumn{3}{|c|}{ HPV 11 results } \\
\hline & & Negative & Positive & Chi-Square Tests & Negative & Positive & Chi-Square Tests \\
\hline \multirow[t]{3}{*}{ Malignant } & Negative & & & \multirow{3}{*}{$\begin{array}{c}1 \\
\text { Chi-Square:0.43 } \\
\text { p-value: } 0.66 \\
\text { p value }>0.05 \\
\text { non significant }\end{array}$} & & & \multirow{3}{*}{$\begin{array}{c}2 \\
\text { Chi-Square:0.00 } \\
\text { p-value:0.99 } \\
\text { p value }>0.05 \\
\text { non significant }\end{array}$} \\
\hline & & $\begin{array}{l}13 / 28 \\
46.4 \%\end{array}$ & $\begin{array}{c}3 / 28 \\
10.7 \%\end{array}$ & & $\begin{array}{c}14 / 28 \\
50 \%\end{array}$ & $\begin{array}{l}2 / 28 \\
7.1 \%\end{array}$ & \\
\hline & Positive & $\begin{array}{c}9 / 28 \\
32.2 \%\end{array}$ & $\begin{array}{c}3 / 28 \\
10.7 \%\end{array}$ & & $\begin{array}{c}9 / 28 \\
32.2 \%\end{array}$ & $\begin{array}{c}3 / 28 \\
10.7 \%\end{array}$ & \\
\hline
\end{tabular}




\begin{tabular}{|c|c|c|c|c|c|c|c|}
\hline \multirow[t]{2}{*}{ Benign } & Negative & $\begin{array}{l}14 / 28 \\
50 \%\end{array}$ & $\begin{array}{c}8 / 28 \\
28.6 \%\end{array}$ & \multirow{2}{*}{$\begin{array}{c}3 \\
\text { Chi-Square: } 2.02 \\
\text { p-value: } 0.043 \\
\text { p value }<0.05 \\
\text { Significant }\end{array}$} & $\begin{array}{l}19 / 28 \\
67.9 \%\end{array}$ & $\begin{array}{c}3 / 28 \\
10.7 \%\end{array}$ & \multirow{2}{*}{$\begin{array}{c}4 \\
\text { Chi-Square: } 0.00 \\
\text { p-value:0.997 } \\
\text { p value }>0.05 \\
\text { non significant }\end{array}$} \\
\hline & Positive & $\begin{array}{c}4 / 28 \\
14.3 \%\end{array}$ & $\begin{array}{l}2 / 28 \\
7.1 \%\end{array}$ & & $\begin{array}{l}2 / 28 \\
7.1 \%\end{array}$ & $\begin{array}{c}4 / 28 \\
14.3 \%\end{array}$ & \\
\hline \multirow[t]{2}{*}{ Control } & Negative & $\begin{array}{c}18 / 20 \\
90 \%\end{array}$ & $\begin{array}{c}0 / 20 \\
0 \%\end{array}$ & \multirow{2}{*}{$\begin{array}{c}5 \\
\text { NA }\end{array}$} & $\begin{array}{c}18 / 20 \\
90 \%\end{array}$ & $\begin{array}{c}0 / 20 \\
0 \%\end{array}$ & \multirow[b]{2}{*}{ NA } \\
\hline & Positive & $\begin{array}{l}2 / 20 \\
10 \%\end{array}$ & $\begin{array}{l}0 / 20 \\
0 \%\end{array}$ & & $\begin{array}{l}2 / 20 \\
10 \%\end{array}$ & $\begin{array}{c}0 / 20 \\
0 \%\end{array}$ & \\
\hline \multicolumn{2}{|c|}{$\begin{array}{l}\text { Chi-Square Tests among } \\
\text { study groups }\end{array}$} & \multicolumn{3}{|c|}{$\begin{array}{c}7 \\
\text { chi-square :2.20, DF: } 2 \\
\text { p-value: } 0.332702 \\
\text { p }>0.05 \\
\text { Non Significant }\end{array}$} & & $\begin{array}{r}\text { chi-square } \\
\text { p-value: } \\
\text { p > } \\
\text { Non Si }\end{array}$ & $\begin{array}{l}\text { DF: } 2 \\
434 \\
\text { ant }\end{array}$ \\
\hline
\end{tabular}

- 1 and 2 refer to that no significant (P>0.05) association between P53 mRNA ISH signal and each of HPV6 and HPV11 ISH signal in malignant group.

- 3 refer to significant $(\mathrm{P}<0.05)$ association between P53 mRNA ISH signal and HPV6 ISH signal in benign group.

- 4 refer to that no significant $(\mathrm{P}>0.05)$ association between P53 mRNA ISH signal and HPV6 ISH signal in benign group.

- 5 and 6 refer to that there was no statistical analysis in control group.

- 7 and 8 refer to that no significant difference $(\mathrm{P}>0.05)$ was found among study groups regarding the association between P53 mRNA and each of HPV6 and HPV11.

\section{IHC P53 With High And Low Risk Types Of HPV DNA.}

In malignant group the percentage of positive results for both over expression of P53 and HPV16 were 8cases (28.6\%) while the positive results of both IHC of P53 results and HPV18 were 7cases (25\%). In benign group the percentage was 10.7\% (3cases) for both of HPV 16 and 18 (Table -3).

Table (3): Association between over expression of P53 and high risk types of human papillomavirus (HPV 16 and 18)

\begin{tabular}{|c|c|c|c|c|c|c|c|}
\hline \multirow{2}{*}{ Groups } & \multirow{2}{*}{$\begin{array}{l}\text { IHC results } \\
\text { of P53 }\end{array}$} & \multicolumn{3}{|c|}{ HPV 16 results } & \multicolumn{3}{|c|}{ HPV 18 results } \\
\hline & & Negative & Positive & $\begin{array}{l}\text { Chi-Square Tests } \\
\end{array}$ & Negative & Positive & Chi-Square Tests \\
\hline \multirow{2}{*}{ Malignant } & Negative & $\begin{array}{l}7 / 28 \\
25 \%\end{array}$ & $\begin{array}{c}3 / 28 \\
10.7 \%\end{array}$ & \multirow{2}{*}{$\begin{array}{c}1 \\
\text { Chi-Square: } 1.35 \\
\text { p-value:0.177 } \\
\text { p value }>0.05 \\
\text { non significant }\end{array}$} & $\begin{array}{l}7 / 28 \\
25 \%\end{array}$ & $\begin{array}{c}3 / 28 \\
10.7 \%\end{array}$ & \multirow{2}{*}{$\begin{array}{c}2 \\
\text { Chi-Square: } 0.67 \\
\text { p-value: } 0.502 \\
\text { p value }>0.05 \\
\text { non significant }\end{array}$} \\
\hline & Positive & $\begin{array}{l}10 / 28 \\
35.7 \%\end{array}$ & $\begin{array}{c}8 / 28 \\
28.6 \%\end{array}$ & & $\begin{array}{l}11 / 28 \\
39.3 \%\end{array}$ & $\begin{array}{l}7 / 28 \\
25 \%\end{array}$ & \\
\hline \multirow{2}{*}{ Benign } & Negative & $\begin{array}{l}12 / 28 \\
42.9 \%\end{array}$ & $\begin{array}{c}10 / 28 \\
35.7 \%\end{array}$ & \multirow{2}{*}{$\begin{array}{c}3 \\
\text { Chi-Square: } 1.90 \\
\text { p-value: } 0.057 \\
\text { p value }>0.05 \\
\text { non Significant }\end{array}$} & $\begin{array}{c}13 / 28 \\
46.4 \%\end{array}$ & $\begin{array}{c}9 / 28 \\
32.2 \%\end{array}$ & \multirow{2}{*}{$\begin{array}{c}4 \\
\text { Chi-Square: } 1.63 \\
\text { p-value: } 0.102 \\
\text { p value }>0.05 \\
\text { non significant }\end{array}$} \\
\hline & Positive & $\begin{array}{c}3 / 28 \\
10.7 \%\end{array}$ & $\begin{array}{c}3 / 28 \\
10.7 \%\end{array}$ & & $\begin{array}{c}3 / 28 \\
10.7 \%\end{array}$ & $\begin{array}{c}3 / 28 \\
10.7 \%\end{array}$ & \\
\hline \multirow{2}{*}{ Control } & Negative & $\begin{array}{l}20 / 20 \\
100 \%\end{array}$ & $\begin{array}{c}0 / 20 \\
0 \%\end{array}$ & 5 & $\begin{array}{l}20 / 20 \\
100 \% \\
\end{array}$ & $\begin{array}{c}0 / 20 \\
0 \%\end{array}$ & 6 \\
\hline & Positive & $\begin{array}{c}0 / 20 \\
0 \% \\
\end{array}$ & $\begin{array}{c}0 / 20 \\
0 \% \\
\end{array}$ & NA & $\begin{array}{c}0 \\
0 \% \\
\end{array}$ & $\begin{array}{l}0 / 20 \\
0 \% \\
\end{array}$ & NA \\
\hline \multicolumn{2}{|c|}{$\begin{array}{l}\text { Chi-Square Tests among } \\
\text { study groups }\end{array}$} & \multicolumn{2}{|c|}{$\begin{array}{c}7 \\
\text { Chi-Squ.:0.23, p-value:0.82 } \\
\text { p }>0.05, \text { Non Significant }\end{array}$} & \multicolumn{4}{|c|}{$\begin{array}{c}8 \\
\text { are:1.05, p-value : } 0.295 \\
.05, \text { Non Significant }\end{array}$} \\
\hline
\end{tabular}

- $1,2,3$, and 4 refer to that no significant (P>0.05) association between of P53 IHC signal and each of HPV16 and HPV18 ISH signal in malignant or in benign group.

- 5 and 6 refer to that there was no statistical analysis in control group.

- 7 and 8 refer to that no significant difference $(\mathrm{P}>0.05)$ was found among study groups regarding the association between P53IHC and each of HPV16 \& 18 ISH signals.

In malignant group the percentage of positive results for P53 IHC and low risk types HPV was 10.7\% ( 3 cases) for HPV6 and 7.1\% ( 2 cases) for HPV11. In benign group the percentage was $10.7 \%$ ( 3 cases) for HPV6 and 0\% for HPV11 (Table -4).The association of P53 over expression and each of HPV16, 18, 6 ISH signals were statistically not significant $(\mathrm{P}>0.05)$ in malignant or in benign group. Only HPV11 
showedsignificant association $(\mathrm{P}<0.05)$ when compared with $\mathrm{P} 53$ over expression results. No significant difference $(\mathrm{P}>0.05)$ was found between HPV types and IHC results of P53 among study groups.

Table (4): Association between over expression of P53 and low risk types of human pappillomavirus (HPV 6 and 11)

\begin{tabular}{|c|c|c|c|c|c|c|c|}
\hline \multirow{2}{*}{ Groups } & \multirow{2}{*}{$\begin{array}{l}\text { IHC } \\
\text { results of } \\
\text { P53 } \\
\end{array}$} & \multicolumn{3}{|c|}{ HPV 6 results } & \multicolumn{3}{|c|}{ HPV 11results } \\
\hline & & Negative & Positive & Chi-Square Tests & Negative & Positive & Chi-Square Tests \\
\hline \multirow[b]{2}{*}{ Malignant } & Negative & $\begin{array}{l}7 / 28 \\
25 \% \\
\end{array}$ & $\begin{array}{c}3 / 28 \\
10.7 \% \\
\end{array}$ & \multirow{2}{*}{$\begin{array}{c}1 \\
\text { Chi-Square:0.43 } \\
\text { p-value: } 0.66 \\
\text { p }>0.05 \\
\text { Non Significant }\end{array}$} & $\begin{array}{l}7 / 28 \\
25 \% \\
\end{array}$ & $\begin{array}{c}3 / 28 \\
10.7 \% \\
\end{array}$ & \multirow{2}{*}{$\begin{array}{c}2 \\
\text { Chi-Square:0.00 } \\
\text { p-value: } 0.997 \\
\text { p > 0.05 } \\
\text { Non Significant }\end{array}$} \\
\hline & Positive & $\begin{array}{c}15 / 28 \\
53.6 \%\end{array}$ & $\begin{array}{c}3 / 28 \\
10.7 \%\end{array}$ & & $\begin{array}{c}16 / 28 \\
57.2 \%\end{array}$ & $\begin{array}{l}2 / 28 \\
7.1 \%\end{array}$ & \\
\hline \multirow[b]{2}{*}{ Benign } & Negative & $\begin{array}{l}15 / 28 \\
53.6 \% \\
\end{array}$ & $\begin{array}{l}7 / 28 \\
25 \% \\
\end{array}$ & \multirow{2}{*}{$\begin{array}{c}3 \\
\text { Chi-Square: } 1.05 \\
\text { p-value: } 0.294 \\
\text { p }>0.05 \\
\text { Non Significant }\end{array}$} & $\begin{array}{c}15 / 28 \\
53.6 \% \\
\end{array}$ & $\begin{array}{l}7 / 28 \\
25 \% \\
\end{array}$ & \multirow{2}{*}{$\begin{array}{c}4 \\
\text { Chi-Square: } 2.42 \\
\text { p-value: } 0.015 \\
\text { p }<0.05 \\
\text { Significant }\end{array}$} \\
\hline & Positive & $\begin{array}{c}3 / 28 \\
10.7 \%\end{array}$ & $\begin{array}{c}3 / 28 \\
10.7 \%\end{array}$ & & $\begin{array}{c}6 / 28 \\
21.4 \%\end{array}$ & $\begin{array}{c}0 / 28 \\
0 \%\end{array}$ & \\
\hline \multirow{2}{*}{ Control } & Negative & $\begin{array}{l}20 / 20 \\
100 \% \\
\end{array}$ & $\begin{array}{c}0 / 20 \\
0 \% \\
\end{array}$ & \multirow[b]{2}{*}{ NA } & $\begin{array}{l}20 / 20 \\
100 \% \\
\end{array}$ & $\begin{array}{c}0 / 20 \\
0 \% \\
\end{array}$ & 6 \\
\hline & Positive & $\begin{array}{c}0 / 20 \\
0 \%\end{array}$ & $\begin{array}{c}0 / 20 \\
0 \%\end{array}$ & & $\begin{array}{c}0 / 20 \\
0 \%\end{array}$ & $\begin{array}{c}0 / 20 \\
0 \% \\
\end{array}$ & NA \\
\hline \multicolumn{2}{|c|}{$\begin{array}{l}\text { Chi-Square Tests among } \\
\text { study groups }\end{array}$} & \multicolumn{3}{|c|}{$\begin{array}{c}7 \\
\text { Chi-Square: } 0.43 \\
\text { p-value: } 0.665 \\
\mathrm{p}>0.05 \text {, Non Significant } \\
\end{array}$} & \multicolumn{3}{|c|}{$\begin{array}{c}8 \\
\text { Chi-Square: } 0.71 \\
\text { p-value: } 0.475 \\
\text { p > 0.05, Non Significant } \\
\end{array}$} \\
\hline
\end{tabular}

- 1 and 2 refer to that no significant $(\mathrm{P}>0.05)$ association between P53 IHC signal and each of HPV6 and HPV11 ISH signal in malignant group.

- 3 refer to that no significant $(\mathrm{P}>0.05)$ association between P53 IHC signal and HPV6 ISH signal in benign group.

- 4 refer to significant $(\mathrm{P}<0.05)$ association between P53 IHC signal and HPV11 ISH signal in benign group.

- 5 and 6 refer to that there was no statistical analysis in control group.

- 7 and 8 refer to that no significant difference $(\mathrm{P}>0.05)$ was found among study groups regarding the association between P53 IHC and each of HPV6 and HPV11 ISH signals.

\section{Ritenoblastoma mRNA With High And Low Risk Types Of HPV DNA}

In malignant group the percentage of positive results for both Rb mRNA and HPV16 DNA was 17.9\% (5cases) while the percentage of positive results for both HPV18 and Rb mRNA was $10.7 \%$ (3cases). In benign group the percentage of positive results for both HPV (16\&18) was $14.3 \%$ (4cases) and $7.1 \%$ (2cases) respectively (Table -5 ).

In the malignant group the percentage of positive results for both Rb mRNA and HPV6\&11 DNA was $14.3 \%$ for HPV6 and $10.7 \%$ for HPV 11. In benign group the percentage was $14.2 \%$ for both HPV6 and HPV11. Only HPV18 DNA showed significant association $(\mathrm{P}<0.05)$ with Rb mRNA ISH signals in benign group (Table -6).

Table (5): Association between Ritenoblastoma mRNA and high risk types of human papillomavirus (HPV 16 and 18)

\begin{tabular}{|c|c|c|c|c|c|c|c|}
\hline \multirow{2}{*}{ Groups } & \multirow{2}{*}{$\begin{array}{l}\text { ISH results } \\
\text { of } \mathrm{Rb}\end{array}$} & \multicolumn{3}{|c|}{ HPV 16 results } & \multicolumn{3}{|c|}{ HPV 18 results } \\
\hline & & Pegative & Positive & 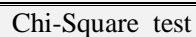 & Negative & Positive & Chi-Square test \\
\hline \multirow[b]{2}{*}{ Malignant } & Negative & $\begin{array}{c}11 / 28 \\
39.3 \%\end{array}$ & $\begin{array}{c}6 / 28 \\
21.4 \%\end{array}$ & \multirow{2}{*}{$\begin{array}{c}1 \\
\text { Chi-Square:0.01 } \\
\text { p-value:0.99 } \\
p>0.05 \\
\text { Non Significant }\end{array}$} & $\begin{array}{c}9 / 28 \\
31.1 \%\end{array}$ & $\begin{array}{c}8 / 28 \\
28.6 \%\end{array}$ & \multirow{2}{*}{$\begin{array}{c}2 \\
\text { Chi-Square: } 1.35 \\
\text { p-value: } 0.17 \\
p>0.05 \\
\text { Non Significant }\end{array}$} \\
\hline & Positive & $\begin{array}{c}6 / 28 \\
21.4 \%\end{array}$ & $\begin{array}{c}5 / 28 \\
17.9 \%\end{array}$ & & $\begin{array}{c}8 / 28 \\
28.6 \%\end{array}$ & $\begin{array}{c}3 / 28 \\
10.7 \%\end{array}$ & \\
\hline \multirow[b]{2}{*}{ Benign } & Negative & $\begin{array}{l}12 / 28 \\
42.9 \% \\
\end{array}$ & $\begin{array}{c}9 / 28 \\
32.1 \% \\
\end{array}$ & \multirow{2}{*}{$\begin{array}{c}3 \\
\text { Chi-Square: } 1.26 \\
\text { p-value: } 0.21 \\
\text { p }>0.05 \\
\text { Non Significant }\end{array}$} & $\begin{array}{c}11 / 28 \\
39.3 \% \\
\end{array}$ & $\begin{array}{c}10 / 28 \\
35.7 \% \\
\end{array}$ & \multirow{2}{*}{$\begin{array}{c}4 \\
\text { Chi-Square:2.28 } \\
\text { p-value:0.02 } \\
\text { p }<0.05 \\
\text { Significant }\end{array}$} \\
\hline & Positive & $\begin{array}{c}3 / 28 \\
10.4 \%\end{array}$ & $\begin{array}{c}4 / 28 \\
14.3 \%\end{array}$ & & $\begin{array}{c}5 / 28 \\
17.9 \%\end{array}$ & $\begin{array}{l}2 / 28 \\
7.1 \%\end{array}$ & \\
\hline
\end{tabular}




\begin{tabular}{|c|c|c|c|c|c|c|c|}
\hline \multirow{2}{*}{ Control } & Negative & $\begin{array}{c}18 / 20 \\
90 \% \\
\end{array}$ & $\begin{array}{c}1 / 20 \\
5 \% \\
\end{array}$ & \multirow{2}{*}{$\begin{array}{c}5 \\
\mathrm{NA}\end{array}$} & $\begin{array}{c}18 / 20 \\
90 \% \\
\end{array}$ & $\begin{array}{c}1 / 20 \\
5 \% \\
\end{array}$ & \multirow{2}{*}{$\begin{array}{c}6 \\
\text { NA }\end{array}$} \\
\hline & Positive & $\begin{array}{l}1 / 20 \\
5 \%\end{array}$ & $\begin{array}{c}0 / 20 \\
0 \%\end{array}$ & & $\begin{array}{l}1 / 20 \\
5 \%\end{array}$ & $\begin{array}{c}0 / 20 \\
0 \%\end{array}$ & \\
\hline \multicolumn{2}{|c|}{$\begin{array}{l}\text { Chi-Square Tests among } \\
\text { study groups }\end{array}$} & \multicolumn{2}{|c|}{$\begin{array}{c}7 \\
\text { Chi-Square:0.00 } \\
\text { p-value:0.997 } \\
\text { p > } 0.05\end{array}$} & \multicolumn{3}{|c|}{$\begin{array}{c}6 \\
\text { Chi-Square:0.00 } \\
\text { p-value: } 0.997 \\
\text { p }>0.05\end{array}$} & \\
\hline
\end{tabular}

- 1 and 2 refer to that no significant $(\mathrm{P}>0.05)$ association between Rb mRNA ISH signal and each of HPV16 and HPV18 DNA ISH signal in malignant group.

- 3 refer to that no significant (P>0.05) association between Rb mRNA ISH signal and HPV16 DNA ISH signal in benign group.

- 4 refer to significant $(\mathrm{P}<0.05)$ association between Rb mRNA ISH signal and HPV18 DNA ISH signal in benign group.

- 5 and 6 refer to that there was no statistical analysis in control group.

- 7 and 8 refer to that no significant difference $(\mathrm{P}>0.05)$ was found among study groups regarding the association between Rb mRNA ISH and each of HPV16\&18 DNA ISH signals.

Table (6): Association between Ritenoblastoma mRNA and low risk types of human papillomavirus (HPV 6 and 11)

\begin{tabular}{|c|c|c|c|c|c|c|c|}
\hline \multirow{2}{*}{ Groups } & \multirow{2}{*}{$\begin{array}{c}\text { ISH results } \\
\text { of } \mathrm{Rb}\end{array}$} & \multicolumn{3}{|c|}{ HPV 6 results } & \multicolumn{3}{|c|}{ HPV 11 results } \\
\hline & & Negative & Positive & Chi-Square test & Negative & Positive & Chi-Square Tests \\
\hline \multirow{2}{*}{ Malignant } & Negative & $\begin{array}{c}15 / 28 \\
53.6 \%\end{array}$ & $\begin{array}{l}2 / 28 \\
7.1 \%\end{array}$ & \multirow{2}{*}{$\begin{array}{c}1 \\
\text { Chi-Square:0.44 } \\
\text { p-value:0.66 } \\
\text { p > } 0.05 \\
\text { Non Significant }\end{array}$} & $\begin{array}{c}15 / 28 \\
53.6 \% \%\end{array}$ & $\begin{array}{c}2 / 28 \\
7.1 \%\end{array}$ & \multirow{2}{*}{$\begin{array}{c}2 \\
\text { Chi-Square:0.00 } \\
\text { p-value: } 0.99 \\
\text { p }>0.05 \\
\text { Non Significant }\end{array}$} \\
\hline & Positive & $\begin{array}{l}7 / 28 \\
25 \%\end{array}$ & $\begin{array}{c}4 / 28 \\
14.3 \%\end{array}$ & & $\begin{array}{c}8 / 28 \\
28.6 \%\end{array}$ & $\begin{array}{c}3 / 28 \\
10.7 \%\end{array}$ & \\
\hline \multirow[b]{2}{*}{ Benign } & Negative & $\begin{array}{l}18 / 28 \\
64.3 \% \\
\end{array}$ & $\begin{array}{c}3 / 28 \\
10.7 \% \\
\end{array}$ & \multirow{2}{*}{$\begin{array}{c}3 \\
\text { Chi-Square: } 0.00 \\
\text { p-value: } 0.997 \\
\text { p }>0.05 \\
\text { Non Significant }\end{array}$} & $\begin{array}{l}18 / 28 \\
64.3 \% \\
\end{array}$ & $\begin{array}{l}3 / 28 \\
7.1 \% \\
\end{array}$ & \multirow{2}{*}{$\begin{array}{c}4 \\
\text { Chi-Square:0.44 } \\
\text { p-value:0.66 } \\
\text { p > } 0.05 \\
\text { Non Significant }\end{array}$} \\
\hline & Positive & $\begin{array}{c}3 / 28 \\
10.7 \%\end{array}$ & $\begin{array}{c}4 / 28 \\
14.3 \%\end{array}$ & & $\begin{array}{c}3 / 28 \\
10.7 \%\end{array}$ & $\begin{array}{c}4 / 28 \\
14.3 \%\end{array}$ & \\
\hline \multirow{2}{*}{ Control } & Negative & $\begin{array}{l}19 / 20 \\
95 \%\end{array}$ & $\begin{array}{l}0 / 20 \\
0 \%\end{array}$ & \multirow{2}{*}{$\begin{array}{c}5 \\
\text { NA }\end{array}$} & $\begin{array}{l}19 / 20 \\
95 \%\end{array}$ & $\begin{array}{c}0 / 20 \\
0 \%\end{array}$ & \multirow{2}{*}{$\begin{array}{c}6 \\
\text { NA }\end{array}$} \\
\hline & Positive & $\begin{array}{l}1 / 20 \\
5 \%\end{array}$ & $\begin{array}{l}0 / 20 \\
0 \%\end{array}$ & & $\begin{array}{l}1 / 20 \\
5 \%\end{array}$ & $\begin{array}{c}0 / 20 \\
0 \%\end{array}$ & \\
\hline
\end{tabular}

- $\quad 1,2,3$, and 4 refer to that no significant $(\mathrm{P}>0.05)$ association between of Rb mRNA ISH signal and each of HPV6 and HPV11 DNA ISH signal in malignant or in benign group.

- 5 and 6 refer to that there was no statistical analysis in control group.

- 7 and 8 refer to that no significant difference $(\mathrm{P}>0.05)$ was found among study groups regarding the association between Rn mRNA ISH and each of HPV16 \& 18 DNA ISH signals.

\section{Discussion}

In malignant group of the present study cases with negative P53 mRNA showing positive HPV16 DNA ISH (17.9\%) were lower than those with positive P53 mRNA showing positive HPV16 DNA ISH (21.4\%). Cases with negative P53 mRNA ISH showing positive HPV18 DNA ISH was higher than those showing positivity in each. However the association was not significant in both malignant and benign group. On testing for low risk viruses, the association in HPV6 and P53 mRNA ISH was significant with benign lesions. Putting in consideration the negative cases for P53 ISH signals indicate absence of the gene or unsuccessful transcription of its mRNA. This could be in part indicated by HPVs. Regarding the over expression of P53, positive IHC expression was seen in positive malignant cases of HPV16\&18 DNA ISH than those with negative HPV16\&18 DNA ISH which is opposite to what is seen in benign group (equal percentages were detected for both HPV16\&18 in positive and nearly equal in negative cases of P53 over expression). The frequencies didn't show significant differences, however, it still reflect an association which could be better expressed if the sample size was larger. Tao et al. 2002, Wu et al 2003 suggested that P53 is one of the most important genetic factors for HPV associated malignances among Chinese people.

Mutant p53 proteins generally have a longer half-life than wild-type p53 proteins and lead to nuclear accumulation (Finlay et al., 1988 and Rogel et al., 1985). Thus, mutant forms of p53 can be detected by immunohistochemistry as nuclear positivity (Lakshmi et al., 1994 and Reihsaus et al., 1990). Wo et al. 2003 
detected positive expression of P53 protein in $42 \%$ of epithelial ovarian cancers. Infection by oncogenic HPV types, especially HPV16, can lead to progression from a benign wart to high-grade cervical dysplasia's which are reversible forms of precancerous lesions. Persistent infection over the years causes irreversible changes leading to carcinoma in situ and eventually invasive cervical cancer. This results from the effects of integrated HPV genes, particularly those encoding E6 and E7 (Angeletti et al., 2008). Additional studies are needed to prove that the variation of E6 proteins in different subtypes of HPV are related to their affinity to P53 protein, especially that the high risk HPV E7 proteins were found to have an approximately ten-fold higher affinity for tumor suppressor proteins $\mathrm{pRb}$ than the low risk HPV E7 proteins (Karl, 1997).

Mutations in P53 were also detected in ovarian cancers ranging from $26 \%$ to $79 \%$ in different studies (Crook et al. 1992; Kohler et al., 1993; Kupryjanczyk et al., 1993; Levine et al., 1994; Milner et al., 1993; Ong et al., 1993; Teneriello et al., 1993; Niwa et al., 1994; and Kmet et al., 2003). Giordano et al. 2008 found positive P53 IHC in $34.3 \%$ of epithelial ovarian tumors. They also found that P53 over expression in ovarian neoplasms is not related to HPV infection. However report suggested that the association between HPV infection and P53 mutation differs among tumors of different origins (Hachisuga et al, 1996; Hasegawa et al, 2002).

Some of these studies suggest that immunohistochemical staining may correlate with the presence of p53 missense mutations in 50-80\% of ovarian tumors (Kupryjanczyk et al., 1993; McManus et al., 1994; Teneriello et al., 1993). Many researchers suggested that HPV may be involved in the development of epithelial ovarian neoplasm's (Ip et al., 1992; Lai et al., 1992; Lai et al., 1994; Wu et al., 2003) similar to the present study. Additional studies looking for particular viral sequences like early protein 6, 7 and 5 in ovarian tissue may be required for final proof. The etiologic role of p53 in ovarian cancer has not been determined, although p53 is often over-expressed, particularly in advanced-stage and poorly differentiated neoplasm's, the true incidence of p53 mutations is not known. Nonsense mutations, splicing mutations, and deletions might not result in p53 accumulation (Kupryanczyk et al., 1993). For this reasons, more specific molecular techniques will be required to study the types of mutation and to link them to the type of HPV infection.

The type of $\mathrm{Rb}$ gene probe used in this study was $\mathrm{Rb} 1 / \mathrm{p} 105$ encoding protein which is the founding member of a three-member family of tumor suppressors which also contains p107 and p130. All three interact with a large number of proteins yet their direct binding to the $\mathrm{E} 2 \mathrm{~F}$ family of transcription factors is fundamental to their roles as tumor suppressors (Sherr\&McCormick, 2002). Mutations in either RB or its pathways are also common in neoplasms of adults (Sherr and McCormick, 2002). Although loss of heterozygosity (LOH) of RB is well demonstrated in many somatic cancers, a specific role of RB in ovarian cancer has been difficult to determine given conflicting data. Previous studies have shown that loss of heterozygosity at the RB/p105 locus is a frequent event in primary ovarian carcinomas (Dodson et al., 1994).

Our study shows that the percentage of HPV18 among negative cases of Rb in benign group was higher than that found in positive cases and statistical analysis was significant suggest that HPV18 may cause deletion to RB gene among benign group.However, there was no significant statistical difference among study groups regarding the association between positive Rb mRNA ISH and positive ISH HPV DNA of other types.

Liu and his workers observed inactivation of $R B$ in $60 \%$ of ovarian cancer samples (Liu et al., 1994), while Gras and his workers reported LOH of the $R B$ locus in $70 \%$ of epithelial ovarian carcinoma (EOC) samples (Gras et al., 2001). However, due to a limited number of samples, statistical significant was not attained in the later study as in our study. Mutations in INK4 protein $p 16, R B$ or $c y c l i n$ Dl/Cdk4 are observed in almost $50 \%$ of EOC clinical samples in a very thorough piece of work (Hashiguchi et al., 2001; Kusume et al., 1999). Of great interest is the observation that over 50\% EOC patients had mutations in both the p53 and RB pathways (Hashiguchi et al., 2001). It is well known that extensive interaction exists between these two pathways (Sherr\& McCormick, 2002).

Many studies have shown p16-INK4a overexpression in high-grade cervical squamous intraepithelial lesions associated with high-risk human papillomavirus (HPV) types, because in this instance, there is functional inactivation of pRb by HPV E7 protein (Giordano et al., 2006 and Keating et al., 2001). Thus, the accumulation of p16 protein is the consequence of loss of the pRb function, which normally inhibits transcription of p16 (Lai et al., 1994). This is an important introduction which explains the importance of additional studies of the relationship between HPV and other proteins.

Besides RB1, additional studies were done on Rb2 and ovarian carcinoma in the presence of HPV types. Giuseppina and his co workers in 2004 found that the $\mathrm{pRb} 2 / \mathrm{p} 130$ expression was detected in benign ovarian surface epithelium but was lost or decreased in most of ovarian carcinoma samples. These results support a role for RB2/p130 as a tumor suppressor gene in human ovarian cancer and suggest that loss of $\mathrm{pRb} 2 / \mathrm{p} 130$ could potentially represent an important marker in the diagnosis and therapy of ovarian carcinoma. In malignant group of the present study the high risk types of HPV (16\&18) were found in high percentages among negative cases of Rb1 mRNA and the same results were found in benign group. For low risk types these results were different whereby positive cases of low risk types of HPV (6\&11) were higher among positive results of Rb1/105 for 
both malignant and benign groups. However, none of the previous studies have shown that there is transcriptional down-regulation of Rb gene by HPV. This needs further proof.

\section{Reference}

[1]. Jawetz E, Melnick JL, and Adelberg's EA: Human cancer virus. Medical microbiology and immunology. 23 ${ }^{\text {Th }}$ edition, Ch 43 . Copy right by the McGraw-Hill companies, Inc, printed by USA (2004): 599-601.

[2]. Werness BA, Levine AJ, Howley PM. The E6 proteins encoded by HPV-16 and 18 can complex p53 in vitro. Science (1990); 248: 76-79

[3]. Dyson N, Howley PM, Munger K, Harlow E. The human papilloma virus-16 E7 oncoprotein is able to bind to the retinoblastoma gene product. Science (1989); 243:934-937.

[4]. Boyle P, Maisonneuve P, Autier P. Update on cancer control in women. Int J. Gynecol. Obstet. (2000); 70: 263-303.

[5]. Zlobec, Russell Steele, René P Michel, Carolyn C Compton, Alessandro Lugl and Jeremy R Jass. Scoring of p53, VEGF, Bcl-2 and APAF-1 immunohistochemistry and interobserver reliability in colorectal cancer. Modern Pathology (2006); 19: 1236-1242.

[6]. Tao Li, Zhe-Ming Lu, Mei Guo, Qin-Jiao Wu, Ke-Neng Chen, Hai-Ping Xing, Qiang Mei, Yang Ke. P53 codon 72 polymorphism (C/G) and the risk of human papillomavirus-associated carcinomas in China. Cancer Journal (2002); 95(12): 2571-2576.

[7]. Wu QJ, Guo M, Lu ZM, Li T, Qiao HZ, Ke Y. Detection of human papillomavirus-16 in ovarian malignancy. Br. J. Cancer (2003); 89: 672675. Repeated

[8]. Finlay CA, Hinds PW, Tan TH, Eliyahu D, Oren M, Levine AJ. Activating mutations for transformation by p53 produce a gene product that forms an hsc70-p53 complex with an altered half-life, Mol. Cell Biol. (1988); 8: 531-539.

[9]. Rogel A, Popliker M, Webb CG, Oren M. p53 cellular tumor antigen: analysis of mRNA levels in normal adult tissues,embryos, and tumors. Mol. Cell Biol. (1985); 5: 2851-2855.

[10]. Lakshmi S, Nair MB, Jayaprakash PG, Rajalekshmy TN, Nair MK, Pillai MR. P53 protein and tumorigenesis in the uterine cervix. Gen. Diagn. Pathol. (1997); 142: 281-287.

[11]. Lakshmi S, Nair MB, Jayaprakash PG, Rajalekshmy TN, Nair MK, Pillai MR. P53 protein and tumorigenesis in the uterine cervix. Gen. Diagn. Pathol. (1997); 142: 281-287.

[12]. Reihsaus E, Kohler M, Kraiss S, Oren M, Montenarh M. Regulation of the level of the oncoprotein p53 in non transformed and transformed cells. Oncogene (1990); 5: 137-145.

[13]. Angeletti PC, Zhang L, and Wood C. "The viral etiology of AIDS-associated malignancies". Adv. Pharmacol. (2008); 56: 509-57.

[14]. Karl RB and Stephen T. "Human Papillomavirus and Human Disease"; The American Journal of Medicine (1997); Vol (102).

[15]. Crook T, Wrede D, Tidy JA, Mason WP, Evans DJ, Vousden KH. Clonal p53 mutation in primary cervical cancer: association with humanpapillomavirus-negative tumours. Lancet (1992);339: 1070-1073.

[16]. Kohler MF, Kerns BM, Humphrey PA, Marks JR, Bast RC, Berchuck A. Mutation and overexpression of p53 in early-stage epithelial ovarian cancer. Obstet. Gynecol. (1993); 81: 643-50.

[17]. Kupryjanczyk J, Thor AD, Beauchamp R, Merritt V, Edgerton SM, Bell DA. P53 gene mutations and protein accumulation in human ovarian cancer. Proc. Natl. Acad. Sci. USA (1993); 90: 4961-5. Repeated repeated

[18]. Levine AJ, Perry ME, Chang A, Silver A, Dittmer D, Wu M, Welsh D. The Walter Hubert Lecture: the role of the p53 tumour-suppressor gene in tumorigenesis. Br. J. Cancer (1994); 69: 409-416.

[19]. Milner BJ, Allan LA, Eccles DM, Kitchener HC, Leonard RC, Kelly KF, Parkin DE, Haites NE. P53 mutation is a common genetic event in ovarian carcinoma. Cancer Res. (1993); 53: 2128-2132.

[20]. Ong CK, Chan SY, Campo MS, Fujinaga K, Mavromara P, Pfister H, Tay SK, Meulen JT, Villa LL, Bernard HU. Evolution of human papillomavirus type 18: an ancient phylogenetic root in Africa and intratype diversity reflect coevolution with human ethnic groups. J. Virol. (1993); 67: 6424-6431

[21]. Teneriello MG, Ebina M, Linnoila RI, Henry M, Nash JD, Park RC, Birrer MJ. P53 and Ki-ras gene mutations in epithelial ovarian neoplasms, Cancer Res. (1993); 53: 3103-3108. repeated

[22]. Niwa K, Itoh M, Murase T. Alteration of p53 gene in ovarian carcinoma: clinicopathological correlation and prognostic significance. Br. J. Cancer (1994); 70:1191-1197

[23]. Giordano G, Adda T D, Gnetti L, Merisio C, Melpignano M. Endometrial mucinous microglandular adenocarcinoma: morphologic, immunohistochemical features and emphasis in the HPV status. Int. J. Gynecol. Pathol. (2006); 25: 77-82. Repeated

[24]. Hachisuga T, Matsuo N, Iwasaka T, Sugimori H, Tsuneyoshi M. Human papilloma virus and p53 overexpression in carcinomas of uterine cervix, lower uterine segment and endometrium. Pathology (1996); 28: 28-31.

[25]. Hasegawa M, Ohoka I, Yamazaki K, Hanami K, Sugano I, Nagao T, Asoh A, Wada N, Nagao K, Ishida Y. Expression of p21/WAF-1, status of apoptosis and p53 mutation in esophageal squamous cell carcinoma with HPV infection. Pathol. Int. (2002); 52: 442-450.

[26]. McManus DT, Yap EP, Maxwell P, Russell SE, Toner PG, McGee JO. P53 expression, mutation, and allelic deletion in ovarian cancer. J. Pathol. (1994); 174: 159-168.

[27]. Ip SM, Wong LC, Xu CM, Cheung AN, Tsang PC, Ngan HY. Detection of human papillomavirus DNA in malignant lesions from Chinese women with carcinomas of the upper genital tract. Gynecol. Oncol. (2002); 87: 104-111.

[28]. Lai CH, Hsueh S, Lin C Y, Huang M Y, You G B, Chang HC, and Pao C C. Human papillomavirus in benign and malignant ovarian and endometrial tissues. Int. J. Gynecol. Pathol. (1992); 11: 210-215.

[29]. Lai CH, Wang CY, Lin CY, Pao CC. Detection of human papillomavirus RNA in ovarian and endometrial carcinomas by reverse transcription/polymerase chain reaction. Gynecol. Obstet. Invest. (1994); 38: 276-280.

[30]. Sherr CJ \&McCormick F. The RB and p53 pathways in cancer. Cancer Cell (2002); 2:103-112. Repeated

[31]. Dodson MK, Cliby WA, Xu HJ, et al. Evidence of functional RB protein in epithelial ovarian carcinomas despite loss of heterozygosity at the RB locus. Cancer Res. (1994); 54: 610-3.

[32]. Liu Y, Heyman M, Wang Y, Falkmer U, Hising C, Szekely L, Einhorn S. Molecular analysis of the retinoblastoma gene in primary ovarian cancer cells. Int. J. Cancer (1994); 58: 663-667.

[33]. Gras E, Pons C, Machin P, Matias-Guiu X, Prat J. Loss of heterozygosity at the RB-1 locus and pRBimmunostaining in epithelial ovarian tumors: a molecular, immunohistochemical, and clinicopathologic study. Int. J. Gynecol. Pathol. (2001); 20: $335-340$.

[34]. Hashiguchi Y, Tsuda H, Yamamoto K, Inoue T, Ishiko O, Ogita S. Combined analysis of p53 and RB pathways in epithelial ovarian cancer. Hum. Pathol. (2001); 32: 988-996. Repeated

[35]. Kusume T, Tsuda H, Kawabata M, Inoue T, Umesaki N, Suzuki T, Yamamoto K. The p16-cyclin D1/CDK4-pRb pathway and clinical outcome in epithelial ovarian cancer. Clin. Cancer Res. (1999); 5: 4152-4157.

[36]. Keating JT, Cviko A, Reithdorf S, Riethdorf L, Quade B J, Sun D, Duensing S, Sheets E E, Munger K, Crum C P. Ki-67, cyclin E and p16 (INK4) are complimentary surrogate biomarkers for human papilloma virus-related cervical neoplasia, Am. J. Surg. Pathol. (2001); 25: 891894.

[37]. GiuseppinaD’Andrilli, Valeria Masciullo, Luigi Bagella, TizianaTonini, CorradoMinimo, Gian Franco Zannoni, Robert L. Giuntoli, II, John A. Carlson, Jr., Dianne Robert Soprano, Kenneth J. Soprano, Giovanni Scambia and Antonio Giordano. Frequent Loss of pRb2/p130 in Human Ovarian Carcinoma. Clinical Cancer Research (2004); 10: 3098-3103. 